\title{
Contribution of conventional bank lending for agricultural sector in Indonesia
}

\author{
Hari Setia Putra; Yunnise Putri*; Ali Anis; Zul Azhar \\ Faculty of Economics, Universitas Negeri Padang, Indonesia \\ *To whom correspondence should be addressed. Email: yunniseputri@ gmail.com

\begin{tabular}{|l|l|l|l|l|}
\hline DOI: & Received: & Revised: & Accepted: & Published: \\
10.22437/ppd.v9i4.13095 & 15.06 .2021 & 06.09 .2021 & 25.10 .2021 & 31.10 .2021 \\
\hline
\end{tabular}

\begin{abstract}
This study examines the determinant contribution of conventional bank lending for the agricultural sector in Indonesia. The analysis method used in this research is the Vector Correction Model (VECM). The results showed that in the short term, there was no significant effect of the Non-Performing Loan (LogNPL), GDP of Agricultural Sector (LogPDB), and Agricultural Sector Credit Interest Rates (SBK). However, there is an effect of the LogNPL and LogPDB on the conventional bank lending for the agricultural sector in the long term. The LogNPL has a significant positive effect on the contribution of conventional bank lending to the agricultural sector. While the LogPDB has a significant negative effect on the contribution of conventional bank lending for the agricultural sector. The Impulse Response Function (IRF) analysis results show that shocks to the LogNPL respond negatively in the long run, shocks to the LogPDB respond positively in the long run, and shocks to the SBK respond negatively in the long run by conventional bank lending for the agricultural sector. Through the analysis of FEVD (Forecast Error Variance Decomposition), it is known that the biggest contribution to conventional bank lending for the agricultural sector is agricultural credit and GDP.
\end{abstract}

Keywords: Agriculture lending, Credit interest rate, Non-performing loan

JEL Classification: Q11, Q13, Q14

\section{INTRODUCTION}

One of the important sectors in supporting the Indonesian economy is agriculture. Due to Indonesia's natural and geographical conditions, which consists of various islands and part of the Indonesian population works as farmers. Apart from having an important role in national development, the agricultural sector also contributes positively to GDP (Mughits \& Wulandari, 2016). The agricultural sector's Gross Domestic Product (GDP) grew in the second quarter of 2020. This increase occurred amid a contraction in business sector growth due to the Covid-19 pandemic. The Central Statistics Agency (BPS) noted that the GDP of the Indonesian agricultural sector in the second quarter of 2020 grew by $2.19 \%$ on an annual basis. The coronavirus pandemic affects the agricultural sector like other sectors because humans can delay travel but cannot delay food needs. So that makes this sector very potential even in pandemic conditions. This also happened during the 1998 crisis when this sector grew 
amidst economic shocks.

The experience of the monetary crisis that occurred in 1998 has made all parties aware that the agricultural sector has a strategic role and a very large role as an engine that drives, dampens shocks, and supports the national economy. Based on real GDP, the agricultural sector has recovered to pre-crisis levels since 1999 or four years faster than the aggregate economy, which recovered in 2003. The agricultural sector is also key to poverty alleviation, food security, and job creation. The agricultural sector is still a mainstay in creating wide employment opportunities (Panekenan, Rumagit, \& Paulus, 2017).

The role of the agricultural sector, in addition to being a major source of foreign exchange earning, is also the source of life for most of the Indonesian population. The agricultural sector absorbs the most labor when viewed from the number of people working. Agricultural development is an absolute prerequisite for improving the community's standard of living. It is reflected in government policies where agriculture is still a top priority (Sayifullah \& Emmalian, 2018). For developing countries like Indonesia, the agricultural sector is the main sector and contributes to the GDP (Tsakok \& Gardner, 2007; Todaro \& Smith, 2012; Fitri et al., 2015).

The GDP of the agricultural sector from year to year also shows an increase by the data on the GDP of the agricultural sector for the last 5 years starting from 2015 to 2019 taken from the website Ministry of Agriculture (Kementan RI) as seen in Figure 1.

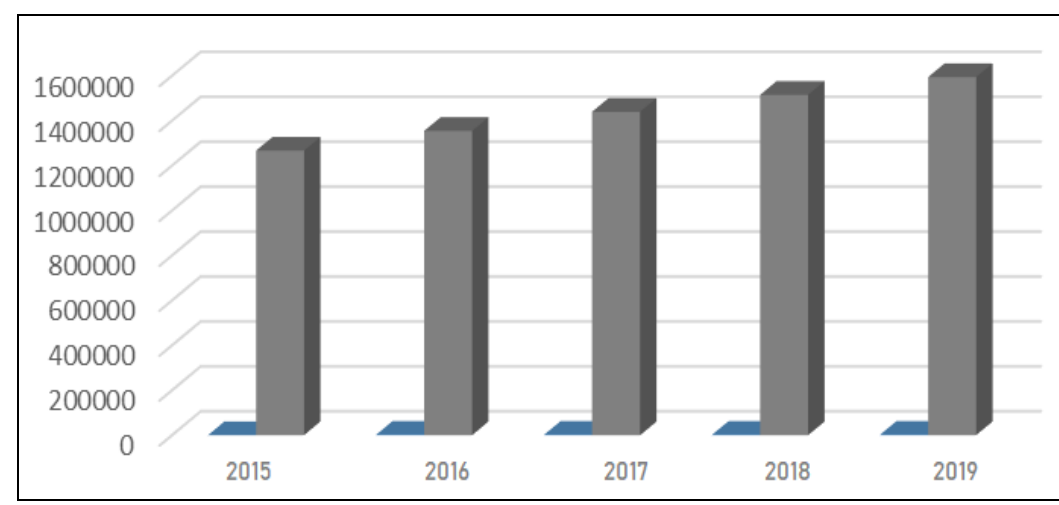

Figure 1. Agriculture sector GDP in 2015-2019 (billion rupiahs)

As a sector that plays a strategic role in development, namely as an absorber of labor, contribution to the GDP, sources of foreign exchange, industrial feedstocks, sources of food and nutrition, as well as driving the movement of other real economic sectors (Enu, 2014; Sertoğlu, Ugural, \& Bekun, 2017; Rusliyadi \& Libin, 2018). However, the agricultural sector still has several problems, one of which is the lack of capital for farmers and business actors in agriculture. To overcome this problem, the banking sector, in theory, has great potential as a support for agricultural financing, which is a formal financial intermediary institution (Ashari, 2009).

Lending in the agricultural sector has a significant role in the growth of GDP in the agricultural sector (Jayusman, 2019). His research stated that bank lending has a positive effect on the GDP of the agricultural sector. For this reason, it is necessary to encourage the banks, especially the BPR, BPD, and BRI, which exist in rural areas, further to enhance their role in lending in the agricultural sector, to encourage growth in the agricultural sector. In addition, the government can also expand credit assistance in the form of real government assistance programs to farmers with easier terms and relatively low-interest rates.

Panekenan (2017) stated that banking in North Sulawesi Province has great 
potential in financing the agricultural sector. Banking financing in North Sulawesi Province for the agricultural sector increases every year. The increased lending in the agricultural sector every year means that the public trusts banks to help strengthen the business capital of agricultural actors in the form of loan provision. In developing agriculture to be even better, financial institutions such as banks are needed to support agricultural business activity capital in the form of credit. Judging from the Indonesian banking statistics, credit to the agricultural sector has recently shown a positive trend, although, in certain months, it has decreased slightly, as seen in Figure 2.

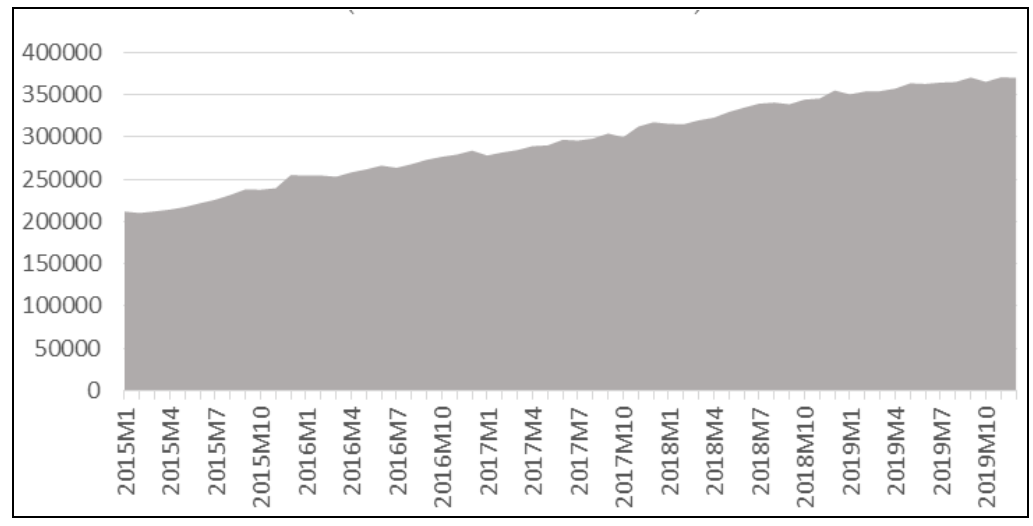

Figure 2. Agricultural credit in 2015-2020 (billion rupiahs)

On the other hand, agricultural sector credit and GDP growth increase every year. Still, non-performing loans in the agricultural sector show fluctuating numbers, ranging from 2015 to 2019, of course, which must be watched out for by the banking sector. Many NPLs illustrate a low return on credit or an increasing number of bad loans. The Indonesian Financial Services Authority page in Indonesian Banking Statistics shows that the agricultural sector's non-performing loans are illustrated in Figure 3.

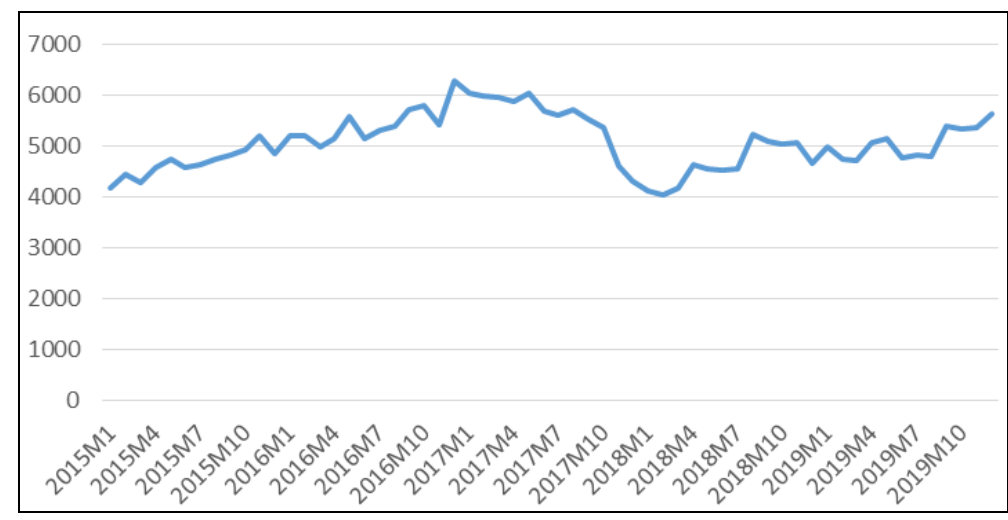

Figure 3. Agricultural sector non-performing loans 2015-2019 (billion rupiahs)

The health quality of bank assets can be measured through NPLs. Asset quality is an assessment of the condition of bank assets and the adequacy of credit risk management. Based on Bank Indonesia Regulation Number 6/23 / DPNP, if a bank has an NPL of more than 5 percent, the bank is declared unhealthy. NPL reflects loan risk. The higher the NPL level, the greater the lending risk borne by banks. Due to high NPLs, banks will be very selective and careful in channeling their credit. It is feared that there is potential for an uncollectible loan (Pratiwi \& Hindasah, 2014). However, based on research conducted by (2017), Non-Performing Loans had no significant effect on lending issued by the bank. 
Based on the background, the authors are interested in raising this issue. This study aims to determine what factors can influence the contribution of sectoral lending distributed by conventional banking in Indonesia for the agricultural sector. Then this study also aims to determine the response received by conventional bank lending for the agricultural sector in Indonesia to shocks that occur in each variable in the long run through Impulse Response Function (IRF) analysis. And to determine the contribution of the influence of each variable on conventional bank lending for the agricultural sector in Indonesia through the analysis of Forecast Error Variance Decomposition (FEVD). So this research is expected to increase the contribution of conventional bank credit to the agricultural sector given the importance of capital to support the success of Indonesian agriculture.

Previous research found that the contribution of Islamic bank financing to the agricultural sector in Indonesia can be seen through several economic indicators, including Islamic banking, monetary and macroeconomic indicators. In the short term, the variables that significantly influence the contribution of Islamic bank financing to the agricultural sector in Indonesia are the rupiah exchange rate variable against the dollar and the SBIS return variable. While in the long term, the variables that significantly influence the contribution of Islamic bank financing to the agricultural sector in Indonesia are the number of third-party funds (DPK) and Non-Performing Financing (NPF) for the agricultural sector (Mughits \& Wulandari, 2016).

Urep (2017) found that the agricultural sector banking credit has a positive and significant effect on the GRDP of the agricultural sector. It means that the greater the bank credit that is given will impact increasing the output and value of GRDP in the agricultural sector in West Kalimantan Province.

The role of government spending, especially in the agricultural sector, has a positive influence on the GDP of the agricultural sector in Indonesia. For this reason, it is hoped that government spending in the agricultural sector needs to be increased. It is recommended for the government that this expenditure be utilized optimally and efficiently by prioritizing financing towards improvement and maintenance of the agricultural sector to support the smooth running of economic activities, especially in the GDP of the agricultural sector. Sayifullah (2018) also found this fact in his study.

According to Ashari (2009), agricultural financing provided by banks is still low due to the high risks of Non-Performing Loan, the complexity of the loan submission process, poor management of agricultural businesses, and limited banking competence in agricultural financing. Research conducted by (Kusumawati, Nuryartono, \& Beik, 2018) found that determinant financing and credit of the construction sector in Indonesia are Third Party Funds, Construction Sector GRDP, GDP per capita, and the percentage of problem financing.

Panekenan et al. (2017) found that banks in North Sulawesi Province have great potential for financing in the agricultural sector. The increase in credit in the agricultural sector means that the public increasingly trusts banks to help strengthen the capital of agricultural business actors in terms of providing loans.

\section{METHODS}

This study uses secondary data from January 2015 to December 2019. The data was obtained from the official website of the Financial Services Authority, namely Indonesian Banking Statistics and the website of the Ministry of Agriculture of the Republic of Indonesia. The variable used is the GDP of the Agricultural Sector. The data is obtained from the website of the Ministry of Agriculture. The data obtained is 
data from years which are then interpolated into monthly data. Next is Agricultural Credit data, Non-Performing Loan data, and credit interest rate data obtained from the official website of the Financial Services Authority in the Indonesian Banking Statistics.

Data analysis in this research used Vector Error Correction Model (VECM). Engle and Granger first popularized this method to correct short-term versus long-term disequilibrium. VECM is a Vector Auto-Regressive (VAR) planned for use on nonstationary data known to have cointegrating relationships. The existence of cointegration in the VECM model makes the VECM model called a restricted VAR. The assumption that must be met in a VECM analysis is that all variables must be stationary in the same order/degree. This is indicated by the residual character of white noise, which has zero mean, constant variance, and no correlation between the dependent variables. The stationarity test aims to identify a unit root in research variables using the Augmented Dickey-Fuller (ADF) test. The existence of cointegration or long-term relationships in the model must also be considered. The presence of this cointegration can be detected using the Johansen or Engel-Granger method. If the variables are not cointegrated, standard VAR can be applied which results will be identical to OLS (Ordinary Least Square). However, if the test proves that there is a cointegration vector, VECM can be applied (Hutabarat, 2017). The test steps include data stationarity test, VAR model stability, optimal lag determination, cointegration test, analysis of Vector Error Correction Model (VECM), Impulse Response Function (IRF), Forecast Error Variance Decomposition (FEVD).

Table 1. Operational definition of variables

\begin{tabular}{ll}
\hline \multicolumn{1}{c}{ Variables } & \multicolumn{1}{c}{ Definition } \\
\hline $\begin{array}{l}\text { Agricultural Credit } \\
\text { (LogCP) }\end{array}$ & $\begin{array}{l}\text { Total agricultural sector credit extended to the public. Agricultural } \\
\text { credit is given by executing banks to business actors in the } \\
\text { agricultural sector to meet financing for working capital, or business } \\
\text { needs to accelerate production or business. }\end{array}$ \\
$\begin{array}{l}\text { Non-Performing } \\
\text { Loanmation of loans classified as substandard, doubtful, and loss as } \\
\text { GDP of Agricultural }\end{array}$ & $\begin{array}{l}\text { stipulated by Bank Indonesia regarding Earning Assets Quality. } \\
\text { The total monetary or market value of all finished goods and services } \\
\text { produced within the borders of a country in a given period. In this } \\
\text { study, the GDP used is the GDP of the agricultural sector. }\end{array}$ \\
Sector (LogPDB) & A price to be paid by the debtor to the bank for a loan in the \\
Agricultural Sector & agricultural sector that has been given. \\
(SBK) &
\end{tabular}

The mathematical equations used in this study are as follows:

$$
\begin{aligned}
& \Delta \log (C P)_{t}=\beta_{0}+\sum_{i=0}^{n} \beta_{2 i \Delta \log (N P L)_{t-1}}+\sum_{i=0}^{n} \beta_{3 i \Delta \log (P D B)_{t-1}}+\sum_{i=0}^{n} \beta_{4 i \Delta S B K_{t-1}}+ \\
& \beta_{5 i} E C T_{t-1}+\varepsilon_{t}
\end{aligned}
$$

Information :

$$
\begin{array}{ll}
\Delta \log (C P) & =\text { Agriculture Lending } \\
\log (\mathrm{NPL})_{\mathrm{t}} & =\text { Non Performing Loan } \\
\log (\mathrm{PDB})_{\mathrm{t}} & =\text { Gross Domestic Product of Agriculture } \\
\mathrm{SBK}_{\mathrm{t}} & =\text { Credit Interest Rate } \\
\alpha_{n i} & =\text { Constant } \\
\varepsilon_{t} & =\text { Error Coefficient } \\
i, n & =\text { Optimum lag } \\
E C T & =\text { Error correction term or disequilibrium error }
\end{array}
$$




\section{RESULTS AND DISCUSSION}

\section{Stationarity test}

One of the important things to remember when analyzing using time series is the condition of the data that is stationary. The meaning of stationery data is when a time sequence data has an average and tends to move towards the average. If the estimation is carried out using data that is not stationary, it will give spurious regression results, according to Gujarati (Hutabarat, 2017). Using Augmented Dickey-Fuller (ADF) test with five percent alpha and data in this research stationary at the first difference level. The results of the stationarity test can be seen in the following table:

Table 2. Stationarity test result

\begin{tabular}{lcccc}
\hline \multirow{2}{*}{ Variables } & \multicolumn{2}{c}{ ADF Value } & \multicolumn{2}{c}{ ADF Value } \\
\cline { 2 - 5 } & Level & Prob. & First & Prob. \\
\hline LogCP & -1.343 .919 & 0.6032 & -1.047 .868 & 0.0000 \\
LogNPL & -2.313 .192 & 0.1713 & -9.226 .411 & 0.0000 \\
LogPDB & -0.485132 & 0.8861 & -8.973 .308 & 0.0000 \\
SBK & -1.943 .557 & 0.3105 & -1.190 .116 & 0.0000 \\
\hline
\end{tabular}

Based on the unit root test result, all the variables in this study were stationary at the first difference with probability 0.0000 percent smaller than the five percent alpha level as presented in the table above.

\section{Lag length test}

The optimal lag length in the VAR system is also carried out to eliminate the autocorrelation problems. So that by using optimal lag, it is expected that autocorrelation problems can be avoided. The optimum lag can be determined by utilizing some information, namely using Akaike Information Criterion and Schwarz Criterion (SC), Likelihood Ratio (LR), Final Prediction Error (FPE), or Hanna-Quin Criterion (HQ).

Table 3. Optimum lag test results

\begin{tabular}{ccclccc}
\hline Lag & LogL & LR & FPE & AIC & SC & HQ \\
\hline 0 & 455.3227 & NA & $1.17 \mathrm{e}-12$ & -16.11867 & $-15.97400^{*}$ & $-16.06258^{*}$ \\
1 & 475.2142 & $36.23089^{*}$ & $1.02 \mathrm{e}-12^{*}$ & $-16.25765^{*}$ & -15.53431 & -15.97721 \\
2 & 488.8890 & 22.95408 & $1.12 \mathrm{e}-12$ & -16.17461 & -14.87259 & -15.66982 \\
3 & 500.5093 & 17.84555 & $1.34 \mathrm{e}-12$ & -16.01819 & -14.13751 & -15.28905 \\
\hline
\end{tabular}

In Table 3, it can be seen that the optimum lag test results state that the optimal lag is at lag 1 by looking at the most asterisks.

\section{VAR stability test}

The stability test of the VAR system needs to be run first before performing further analysis. The Impulse Response Function and Forecast Error Decomposition will be invalid if the VAR estimation is unstable.

Table 4. VAR stability test results

\begin{tabular}{cl}
\hline Root & Modulus \\
\hline-0.460040 & 0.460040 \\
-0.425694 & 0.425694 \\
-0.332791 & 0.332791 \\
-0.126348 & 0.126348 \\
\hline
\end{tabular}

Based on Table 4, it can be seen that the VAR model is stable because the greatest 
modulus value is less than one and is at the optimal point, so it can be said that the model is in the optimal position and the VAR model is stable.

\section{Cointegration test}

A cointegration test is performed when the data is stationary at the first difference to see the possibility of cointegration between research variables. Cointegration is a combination of linear relationships of non-stationary variables, where all of these variables must be integrated into the same order or degree, with no cointegration relationship. The analysis is carried out using the VAR difference method (VAR with all stationary variables at different levels). If there is a cointegration relationship, VECM analysis can be performed.

This cointegration test can be done using the Engle-Granger test or the Johansen test. The cointegration test itself is one of the methods used to determine whether there is a long-term relationship and balance between the variables that are stationary at the first difference level. Based on the table below, it can be seen that all variables have cointegration because the probability is smaller than alpha by 5 percent. Apart from using probability and real level comparisons, long-term information can also be determined through criteria based on trace statistical values. Suppose a trace statistic is greater than a critical value (five percent). In that case, alternative hypotheses are accepted, and thus can be seen how many equations are integrated into the system can be seen. Based on the table below, the cointegration test result can be seen from the trace statistic value greater than the critical value of five percent.

Table 5. Cointegration test results

\begin{tabular}{|c|c|c|c|c|}
\hline Hypothesized & & Trace & 0.05 & \\
\hline No. of $\mathrm{CE}(\mathrm{s})$ & Eigenvalue & Statistic & Critical Value & Prob.** \\
\hline None * & 0.683947 & 151.4641 & 47.85613 & 0.0000 \\
\hline At most $1 *$ & 0.468318 & 85.80884 & 29.79707 & 0.0000 \\
\hline At most $2 *$ & 0.416623 & 49.80134 & 15.49471 & 0.0000 \\
\hline At most $3 *$ & 0.284509 & 19.08282 & 3.841466 & 0.0000 \\
\hline
\end{tabular}

\section{VECM estimation method}

The VECM estimation results will obtain a short and long-term relationship between agricultural lending, non-performing loans, agricultural GDP, and credit interest rates. Agricultural Credit becomes the dependent variable in this estimate, while other variables become the independent variable. The VECM results to see the longterm and short-term effects of the dependent variable on the independent variable can be seen in the table.

In the table, it can be seen the results of the VECM method in the short and long term. In the short term, the VECM results show an error correction of 0.146050 , which is statistically significant. Correction of errors means that the disequilibrium will be corrected by 0.146050 percent to return to its long-term equilibrium in the following month.

Based on the table, it can be concluded that in the term, none of the variables in the study significantly affect conventional banking credit for the agricultural sector in Indonesia. However, in the long term, several variables significantly influence conventional bank lending for the agricultural sector in Indonesia. The Non-Performing Loan (LogNPL) variable and GDP for agriculture (LogPDB) are among them. In this study, Non-Performing Loan (LogNPL) variable has a significant positive effect on conventional bank lending for the agricultural sector of 0.195175. It means that when 
there is an increase in the variable Non-Performing Loans by one percent, it will increase conventional banking credit for the agricultural sector by 0.195175 percent.

Table 6. Factors affecting long-term agricultural credit

\begin{tabular}{lccc}
\hline Variables & Coefficient & T-Statistic & $\begin{array}{c}\text { Information } \\
(T-T a b l e=2.00324)\end{array}$ \\
\hline LogNPL & 0.195175 & {$[2.37623]$} & Significant \\
LogPDB & -1.751240 & {$[-3.34141]$} & Significant \\
SBK & 0.018803 & {$[0.34872]$} & Not significant \\
C & 6.008009 & & \\
\hline
\end{tabular}

Table 7. Factors affecting agricultural credit in the short term

\begin{tabular}{|c|c|c|c|}
\hline Variables & Coefficient & T-Statistic & $\begin{array}{c}\text { Information } \\
(\mathrm{T}-\mathrm{Table}=2.00324)\end{array}$ \\
\hline CointEq1 & -0.146050 & {$[-2.26359]$} & Significant \\
\hline $\mathrm{D}(\operatorname{LOG}(\mathrm{CP}(-1)))$ & -0.216801 & {$[-1.49195]$} & Not significant \\
\hline D(LOG(NPL(-1))) & 0.020850 & [ 0.59156$]$ & Not significant \\
\hline $\mathrm{D}(\operatorname{LOG}(\mathrm{PDB}(-1)))$ & -0.142783 & {$[-0.87480]$} & Not significant \\
\hline $\mathrm{D}(\mathrm{SBK}(-1))$ & 0.003523 & {$[0.14881]$} & Not significant \\
\hline $\mathrm{C}$ & 0.014079 & [ 4.60311] & Significant \\
\hline
\end{tabular}

It shows that when there is an increase in the ratio of bad loans in the agricultural sector, the contribution of conventional bank lending for the agricultural sector also increases because more lending is distributed to farmers. The results of this study are different from the results found by Haryanto \& Widyarti (2017), who found that NPLs had no significant and positive effect on lending. Other research conducted by Pratiwi \& Hindasah (2014) found that NPL is negative and significant at the 5\% significance level. His research stated that the higher the NPL, the greater the credit risk is borne by the banking sector. Due to high NPLs, banks will be very selective and careful in channeling their credit. It is feared that there is potential for uncollectible credit.

Meanwhile, the agricultural sector's GDP (LogPDB) had a significant negative effect on conventional banking credit for the agricultural sector by 1.751240 percent. These results conclude that when there is an increase in the GDP of the agricultural sector in the long run by one percent, it will result in a decrease in conventional banking credit for the agricultural sector by 1.751240 percent.

It shows when the GDP of the agricultural sector increase, which means the welfare of farmers increases, farmers in developing their business do not depend on loans given by banks anymore. So conventional bank lending for the agricultural sector decreases. The results of this study are different from the research conducted by Ramelda (2017), who found that GDP has a positive effect on lending.

\section{Impulse Response Function (IRF)}

IRF (Impulse Response Function) analysis will explain the impact of shocks (shocks) on one variable on other variables, which in this analysis is not only short-term but can be analyzed for several horizons in the future as long-term information. In this analysis, one can see the long-term dynamic response of each variable if there is a certain shock of one standard error in each equation. The Impulse Response Function analysis also determines how long this influence lasts. IRF aims to see the responses of each variable due to changes in the shock of a particular variable. In this study, shocks will be seen in the Non-Performing Loan (LogNPL) variable, agricultural sector GDP 
(LogPDB), and Credit Interest Rate (SBK) against conventional banking credit for the agricultural sector.

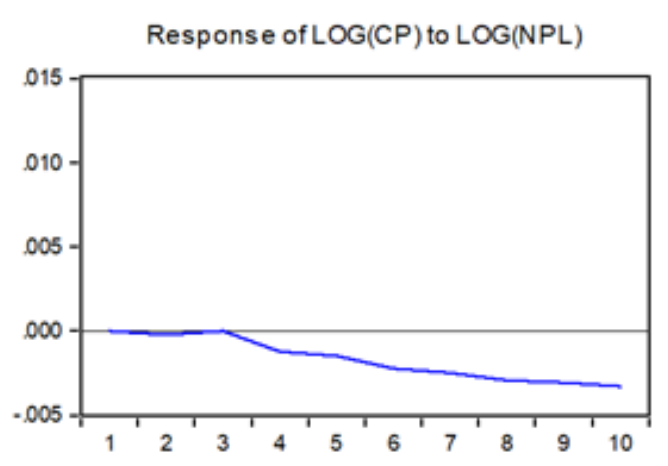

Figure 5. Response of agriculture loan to non-performing loan

Figure 5 shows the response received by conventional banking credit for the agricultural sector in Indonesia from shocks that occurred in the Non-Performing Loan (LogNPL) variable, which responded negatively in the long term with a standard deviation of -0.000248 in the second period. This negative response continues until the next period, as seen in the figure. In the third to last period, the negative response is getting bigger with a standard deviation in the last period of -0.003301 .

Response of $L O G(C P)$ to $L O G(P D B)$

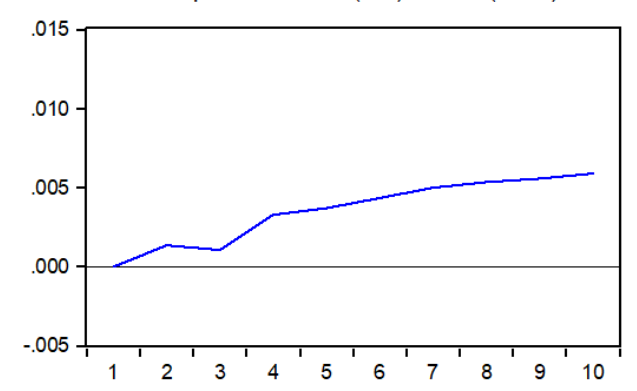

Figure 6. Response of agriculture loan to the GDP of agriculture

Figure 6 is a shock response that occurs in the agricultural sector GDP (LogPDB) variable to conventional banking credit for the agricultural sector in Indonesia, which has a positive response in the long term. In Figure 6, agricultural credit responded positively to shocks to the GDP variable starting from the first period with a standard deviation of 0.001333 in the second period. In the 5th period, the standard deviation was 0.003684 . Until the 10th period, the shock is getting bigger. It can be seen from the standard deviation value of 0.005875 .

Response of $L O G(C P)$ to $S B K$

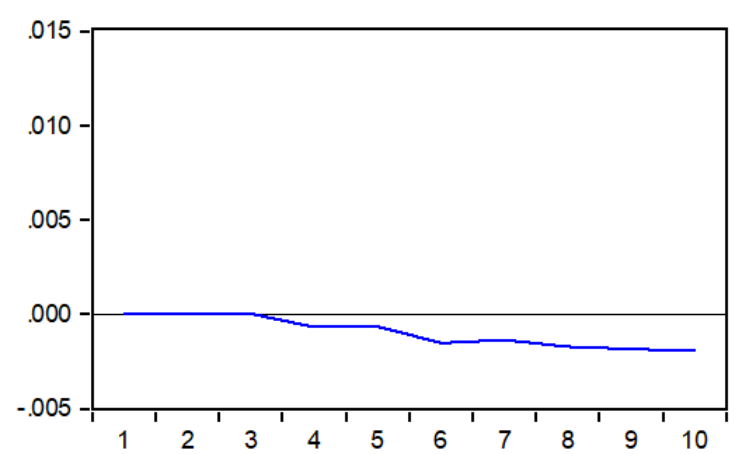

Figure 7. Response of agriculture loan to interest rate 
Figure 7 shows how the response of agricultural credit to shocks that occur in the variable lending rate (SBK). Conventional banking credit for the agricultural sector initially responded positively to the shocks that occurred in the SBK variable. However, the positive response received did not last long. It can be seen in the figure that before the 4th period, a positive response turned into a negative response with a standard deviation value in the fourth period of -0.000686 . This negative response lasted until the 10 th period with a standard deviation of -0.001943 .

\section{Analysis of Forecast Error Variance Decomposition (FEVD)}

The Forecast Error Variance Decomposition analysis aims to measure the number of contributions each independent variable has on the dependent variable. Table 8 shows how the Forecast Error Variance Decomposition (FEVD) analysis results, the equation for the amount of lending extended by conventional banking to the agricultural sector in Indonesia. In the first period, the diversity of agricultural credit fluctuations was dominated by agricultural financing by one hundred percent, continued until the end of the period with decreasing contributions.

Table 8. Variance decomposition

\begin{tabular}{cccccc}
\hline Period & S.E. & LOG(CP) & LOG(NPL) & LOG(PDB) & SBK \\
\hline 1 & 0.013784 & 100.0000 & 0.000000 & 0.000000 & 0.000000 \\
2 & 0.016594 & 99.33109 & 0.022420 & 0.645079 & 0.001411 \\
3 & 0.018515 & 99.14586 & 0.018225 & 0.834761 & 0.001154 \\
4 & 0.020802 & 96.37314 & 0.371974 & 3.145326 & 0.109565 \\
5 & 0.022708 & 93.80365 & 0.750313 & 5.271047 & 0.174986 \\
6 & 0.024803 & 90.53395 & 1.453875 & 7.490920 & 0.521257 \\
7 & 0.026810 & 87.32464 & 2.112710 & 9.858130 & 0.704522 \\
8 & 0.028822 & 84.18516 & 2.865341 & 11.97698 & 0.972519 \\
9 & 0.030766 & 81.48337 & 3.509152 & 13.79531 & 1.212167 \\
10 & 0.032686 & 78.99104 & 4.129058 & 15.45278 & 1.427125 \\
\hline
\end{tabular}

In the second period, the contribution of other variables has started to emerge where LogNPL contributed 0.02 percent, LogPDB variable contributed 0.65 percent, the SBK variable contributed 0.00 percent. In the fifth period, agricultural credit contributed 93.80 percent to its fluctuation. The role of other variables such as LogNPL of 0.75 percent, the LogPDB variable contributed an increasing contribution of 5.27 percent and the SBK variable of 0.17 percent. Then in the last period, namely the tenth period, the contribution of Agricultural credit ( $\log C P)$ to its fluctuations decreased by 78.99 percent, the LogNPL variable was 4.12 percent, the LogPDB variable contribution increased by 15.45 percent, and the SBK variable was 1.43 percent. So it can be seen from the table below that the largest contribution to the agricultural lending variable is shown by the agricultural sector GDP $(\operatorname{LogPDB})$ variable of 15.45 percent.

\section{CONCLUSIONS AND RECOMMENDATIONS}

\section{Conclusions}

The results of the VECM estimation carried out, in the short term, none of the research variables affected the contribution of conventional bank lending for the agricultural sector. Meanwhile, in the long term, the contribution of conventional bank lending is influenced by non-performing loans and GDP.

Results of the IRF shocks that occur in the non-performing loan, negative response in the long term starts from the first to the last period. Shocks that occur in the 
agricultural sector GDP have a positive response in the long term by agricultural credit. Agricultural credit began to respond positively to shocks to the GDP from the first to the end of the period.

Meanwhile, agricultural credit initially responded positively to the shocks that occurred for the credit interest rate. However, the positive response received did not last long. Towards the fourth period, has positive response turned into a negative response. This negative response lasted until the 10th period. Results of the FEVD analysis show that the variable that most influences agricultural credit is dominated by the variable itself by 100 percent in the first period and continues to decline in the following period until the end of the period. Another variable that contributed significantly was the GDP of the agricultural sector, followed by the non-performing loan and the credit interest rate.

\section{Recommendations}

Indonesia's geographical conditions that support the agricultural sector, the government should pay great attention to improving this sector. With the government's attention, such as increasing the amount of credit in the agricultural sector and providing other assistance that directly or indirectly affects farmer production, it is hoped that this sector will be able to progress in the Indonesian economy if it is managed properly.

\section{REFERENCES}

Ashari. (2009). Optimalisasi Kebijakan Kredit Program Sektor Petanian Di Indonesia. Analisis Kebijakan Pertanian, 7(1), 21-42.

Enu, P. (2014). Analysis Of The Agricultural Sector Of Ghana And Its Economic Impact On Economic Growth. Academic Research International, 5, 267-277

Fitri, N. Syechalad, M.N., \& Syahnur, S. (2015). Analisis Faktor-Faktor Yang Mempengaruhi Produksi Padi Di Propinsi Aceh. Jurnal Ilmu Ekonomi, 3(1), 5360.

Haryanto, S. B., \& Widyarti, E. T. (2017). Analisis Pengaruh Nim, Npl, Bopo, Bi Rate Dan Car Terhadap Penyaluran Kredit Bank Umum Go Public Periode 2012-2016. Journal Of Management, 6(4), 1-11.

Hutabarat, M. (2017). Pemodelan Hubungan Antara Ihsg, Nilai Tukar Dolar Amerika Serikat Terhadap Rupiah (Kurs) Dan Inflasi Dengan Vector Error Correction Model (Vecm). [Thesis, Universitas Pendidikan Indonesia]. Http://Repository.Upi.Edu/28854/

Jayusman. (2019). Pengaruh Investasi PMA Dan Kredit Perbankan Sektor Pertanian Terhadap Penyerapan Tenaga Kerja dan PDRB Sektor Pertanian Di Provinsi Kalimantan Barat. Jurnal Ekonomi Daerah, 7(1).

Kusumawati, N. N., Nuryartono, N., \& Beik, I. S. (2018). Analisis Pembiayaan Dan Kredit Sektor Konstruksi Di Indonesia: Studi Perbankan Syariah Dan Konvensional. Jurnal Ekonomi Dan Kebijakan Pembangunan, 6(1), 21-40. Https://Doi.Org/10.29244/Jekp.6.1.21-40

Mughits, M., \& Wulandari, R. (2016). Kontribusi Pembiayaan Bank Syariah Untuk Sektor Pertanian Di Indonesia Contribution Of Islamic Bank Financing For Agricultural Sector In Indonesia. Jurnal Al-Muzara'ah, 4(1), 61.

Panekenan, D., Rumagit, G. A. ., \& Paulus, A. P. (2017). Peran Kredit Perbankan Pada

Sektor Pertanian Di Provinsi Sulawesi Utara. Agri-Sosio Ekonomi, 13, 183-194.

Pratiwi, S., \& Hindasah, L. (2014). Pengaruh Dana Pihak Ketiga, Capital Adequacy 
Ratio, Return Nn Asset, Net Interest Margin Dan Non Performing Loan Terhadap Penyaluran Kredit Bank Umum Di Indonesia. Jurnal Manajemen Bisnis Universitas Muhammadiyah Yogyakarta, 5(2), 192-208.

Ramelda, S. (2017). Pengaruh Suku Bunga Kredit Dan Produk Domestik Bruto Terhadap Penyaluran Kredit Perbankan Bank Umum Pemerintah Di Indonesia. Jomfekom, 4(1), 843-857.

Rusliyadi, M. \& Libin, W. (2018). Agriculture Development Programs For Poverty

Reduction Evidences From Indonesia And China - Comparative Study Case. Asian Journal Of Agriculture And Rural Development, 8(2), 104-118

Sayifullah, S., \& Emmalian, E. (2018). Pengaruh Tenaga Kerja Sektor Pertanian Dan Pengeluaran Pemerintah Sektor Pertanian Terhadap Produk Domestik Bruto Sektor Pertanian Di Indonesia. Jurnal Ekonomi-Qu, 8(1). Https://Doi.Org/10.35448/Jequ.V8i1.4962

Sertoglu, K., Ugural, S., \& Bekun, F. V. (2017). The Contribution Of Agricultural Sector On Economic Growth Of Nigeria. International Journal Of Economics And Financial Issues, 7, 547-552.

Todaro M.P., \& Smith S. (2012). Economic Development (11th Edition). Pearson

Tsakok I., \& Gardner B. (2007). Agriculture In Economic Development: Primary Engine Of Growth Or Chicken And Egg? American Journal Of Agricultural Economics, 89(5): 1145-1151 